\title{
Regional seismic stratigraphic correlations of the Ross Sea: Implications for the tectonic history of the West Antarctic Rift System
}

\author{
Robert C. Decesari, ${ }^{1,2}$ Christopher C. Sorlien, ${ }^{1}$ Bruce P. Luyendyk, ${ }^{1}$ Douglas S. Wilson, ${ }^{1,3}$ Louis Bartek, ${ }^{4}$ \\ John Diebold, ${ }^{5}$ and Sarah E. Hopkins ${ }^{1}$ \\ ${ }^{1}$ Dept. of Earth Sciences and Inst. for Crustal Studies, University of California, Santa Barbara, CA 93106 USA (robert.c.decesari@exxonmobil.com) \\ (chris@crustal.ucsb.edu)(luyendyk@geol.ucsb.edu) \\ ${ }^{2}$ now at ExxonMobil Exploration Co., Houston TX \\ ${ }^{3}$ Marine Science Institute, University of California, Santa Barbara, CA 93106 USA (wilson@geol.ucsb.edu) \\ ${ }^{4}$ Department of Geological Sciences, University of North Carolina, Chapel Hill, NC.27599 USA \\ ${ }^{5}$ Lamont-Doherty Earth Observatory of Columbia University, Palisades, NY. 10964 USA.
}

\begin{abstract}
Using existing and new seismic reflection data, new and updated correlations of late Oligocene-early Miocene RSS-2 strata were made between the southern parts of Ross Sea basins. Previous studies documented Cretaceous extension across much of Ross Sea. We interpret that Cenozoic extension also occurred across Ross Sea. Subsidence during and following this extension deepened existing basins and may have initiated basins in the west, subsiding ridges between basins below sea level during the late Oligocene. Pre-Oligocene strata record cessation of L. Cretaceous extension in easternmost Ross Sea. Successively younger Cenozoic extension occurred from east to west across the rest of Ross Sea.

Citation: Decesari, R.C., C.C. Sorlien, B.P. Luyendyk, D.S. Wilson, L. Bartek, J, Diebold and S.E. Hopkins. (2007), Regional seismic stratigraphic correlations of the Ross Sea: Implications for the tectonic history of the West Antarctic Rift System, in Antarctica: A Keystone in a Changing World - Online Proceedings of the $10^{\text {th }}$ ISAES, edited by A.K. Cooper and C.R. Raymond et al., USGS Open File Report 2007-1047, Short Research Paper 052, 4 p.; doi:10.3133/of2007-1047.srp052
\end{abstract}

\section{Introduction}

The Ross Sea is composed of four sedimentary basins filled with kilometers of sedimentary rocks and separated by basement highs. The Ross Sea overlies extended lithosphere of the West Antarctic Rift System (WARS) between East and West Antarctica. Extension in the rift is thought to have occurred in two episodes; in the Cretaceous and Cenozoic (Davey and Brancolini, 1995). Proposed timing of geologic events between basins can be questioned because coring results on the flank of Victoria Land Basin (VLB) demonstrate prior stratigraphic interpretations (e.g., Brancolini, et al., 1995) overestimated VLB stratal ages. The goal of this study is to correlate the stratigraphy of the eastern and western Ross Sea to better understand the nature, structure, and tectonic history of the WARS. Although ANTOSTRAT (1995) correlations of late Oligocene-early Miocene strata between basins are accurate in the northwestern Ross Sea (Fig. 1), there is a perception that it is not possible to correlate Cenozoic strata between basins. This paper presents direct correlations of Cenozoic stratigraphic sequences across the Ross Sea using previously available and recently acquired seismic reflection data.

Studies propose the Ross Sea was at high elevations before crustal thinning due to Cretaceous rifting (Decesari, 2006; Luyendyk, et al., 2001). Two rifting events can explain the thicknesses of mid-Cenozoic strata found in the Ross Sea (Decesari, 2006). Our seismic reflection data and regional stratigraphic correlations allow study of deposition and erosion of mid-Cenozoic strata at the edges of the basins using stratal geometry to infer the ages of basin subsidence.

The strata of the Ross Sea (Table 1) are separated into the $\mathrm{V}$ sequences (V1 oldest-V7 youngest) of the western
Ross Sea (Cooper, et al., 1987) and the Ross Sea sequences (RSS-1 oldest-RSS-8 youngest) of the eastern Ross Sea (Luyendyk, et al., 2001). "RSS" and "RSU" (Ross Sea unconformity) nomenclature will be used in this paper for clarity.

Two marine geophysical surveys were conducted in 2003 and 2004 along the Ross Ice Shelf front during RVIB Nathaniel B. Palmer cruises 03-01 (NBP-0301) and 03-06 (NBP-0306) (Fig. 1). The cruises collected $>4,500$ $\mathrm{km}$ of new multichannel reflection data and $>3,600 \mathrm{~km}$ of single channel reflection data. A survey site was chosen where iceberg C-19 broke off the ice shelf adjacent to Ross Island in 2002 and spans the structural provinces of the VLB, Coulman High (CMH), and Central Trough (CT). Another survey was chosen where iceberg B-15

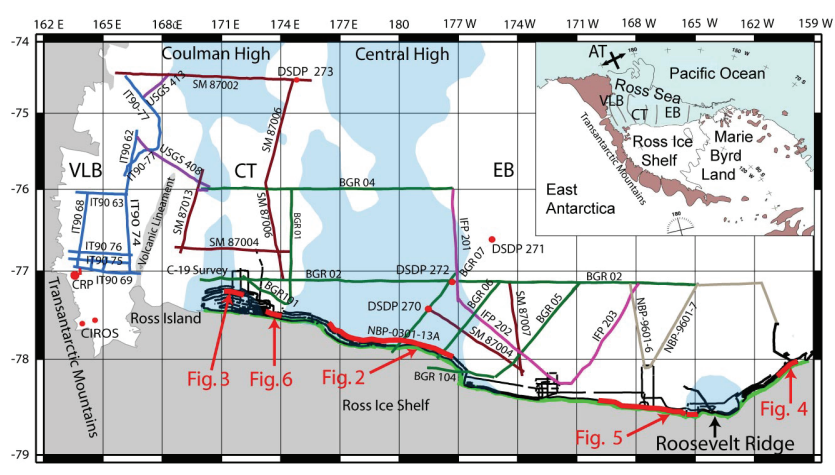

Figure 1. Ross Sea correlations. EB and VLB RSS-2 strata tied along colored labeled seismic lines from the EB to the CT and from CRP to the CT. Figures 2-6 = heavy red lines. Inset Map: AT=Adare Trough. Blue $=$ structural highs. Green $=2003-2004$ ice shelf edge. 
Table 1. Proposed Ross Sea strata correlation (after Luyendyk et al., 2001).

\begin{tabular}{|c|c|c|c|}
\hline RSS sequence & Unconformity & Age & $V$ sequence \\
\hline RSS-4-RSS-8 & RSU4-RSU1 & $\begin{array}{l}\text { E. Miocene- } \\
\text { Pleistocene }\end{array}$ & V3?-V1 \\
\hline RSS-3 & & E. Miocene & V3 \\
\hline RSS-2-upper & Local unconf. & $\begin{array}{l}\text { L. Oligocene - } \\
\text { E. Miocene }\end{array}$ & V4 \\
\hline RSS-2-lower & RSU6 & & \\
\hline RSS-1-upper & RSU7 & $>$ E. Oligocene? & V5? \\
\hline RSS-1-lower & & L. Cretaceous? & $? ?$ \\
\hline
\end{tabular}

calved in 2000, and covers the extent of Eastern Basin (EB). Advanced seismic processing methods were used, including velocity analysis and multiple attenuation techniques, such as Radon or F-K filtering, resulting in images below $3 \mathrm{~s}$ two way travel time in the basins.

\section{Correlation study and regional stratigraphy}

We correlated late Oligocene unconformity RSU6, early Miocene unconformity RSU5, and intervening RSS2 from Deep Sea Drilling Project (DSDP) Sites 270 and 272 on the west flank of EB, across Central High (CH), and westward into $\mathrm{CT}$, along two paths near $76^{\circ} \mathrm{S}$ and $78^{\circ}$ S (Fig. 1). RSS-2 strata were also correlated from CT across CMH into VLB via two paths. The existing ANTOSTRAT (1995) correlation across the CMH and $\mathrm{CH}$ at $76^{\circ} \mathrm{S}$ was found to be essentially correct, where part of RSS-2 can be correlated across. Part of middle Miocene RSS-3 was also correlated across $\mathrm{CH}$ on this profile (ANTOSTRAT plate 9). We determined the ANTOSTRAT (1995) RSS-2 correlation across the CMH was correct at $74.5^{\circ} \mathrm{S}$ (ANTOSTRAT plate 8). A miscorrelation by ANTOSTRAT (1995) was found between northern and southern VLB, and between south CMH across volcanic lineaments into southern VLB. The miscorrelation was probably due to complex geology that is difficult to image. Miscorrelation along the N-S axis of VLB was likely due to the great depth of RSS-2, multiple reflections in the Italian (IT90) and USGS data, and numerous faults not accounted for offsetting RSS-2.

Davey et al. (2000) correlated CRP stratigraphy into southern VLB. From there, we correlated the top of RSS2 (RSU5) between northern and southern VLB along the west flank of VLB where RSS-2 is shallow (Fig. 1). Our new seismic reflection data along the ice shelf front allowed correlation of RSS-2 across Central High (Fig. 2). The V4 and RSS-2 sequences, known to be about the same age from coring, are a continuous Ross Sea-wide unit. In EB, RSS-2-lower was correlated from near DSDP-270 to Roosevelt Sub-basin in southeastern Ross Sea as described in Sorlien et. al. (2007) (Fig 1).
We focus our discussion of Ross Sea stratigraphy to areas near the current ice shelf front and the rocks regionally preserved there. These rocks are interpreted as Cretaceous to early Miocene age. We interpret two stratigraphic units beneath unconformity RSU6 (Fig. 2 \& $3)$. RSS-1-lower is defined by highly tilted, discontinuous, and faulted reflections. RSS-1-upper is defined by continuous reflections cut by few and discrete higher angle faults. These sequences are separated by angular unconformity RSU7 and truncated by RSU6 (Fig. 2 \& 3, Table 1). The RSS-1 units cannot be correlated between basins because RSS-1-lower is too disrupted for regional correlations and RSS-1-upper is only present in isolated grabens on basement highs (Fig. 3). RSS-1 does not appear to be synchronous across Ross Sea.

RSS-1-upper is little deformed and up to 500 meters thick in the Roosevelt Sub-basin (Fig. 1 \& 4), similar to EB RSS-1-upper. RSS-1-upper onlaps Marie Byrd Land to the east of Roosevelt Sub-basin (Fig. 4), and onlaps Roosevelt Ridge to the west (Sorlien, et al., 2007). RSS-2 does not significantly onlap Roosevelt Ridge along the eastern flank of the EB; instead, the 2000 m-thick interval (including RSS-3 and RSS-4) is eroded at a composite early and mid-Miocene unconformity (Fig. 5). RSS-2 onlaps $\mathrm{CH}$ from both sides, preventing RSS-2 from being cored at DSDP Site 270 (Fig 2; Steinhauff et. al., 1987).

\section{Discussion and conclusions}

Accurate correlations are needed to understand the timing and magnitude of Ross Sea tectonic and climatic events. Lithologic comparisons of RSS-2, cored at DSDP Site 270 in EB, to unit V4, cored at CRP in VLB, show both units are composed of similar strata of early Miocene age ( 19.2-21 Ma; Cape-Roberts-Science-Team, 2000; Steinhauff et. al., 1987).

The sedimentation and erosion history of RSS-1-upper and RSS-2 provide information on vertical tectonics related to Ross Sea extension. Seismic reflection data indicate two periods of extension occurred; first in the L. Cretaceous, recorded by highly deformed and faulted RSS-1-lower and a second phase in the Tertiary, recorded

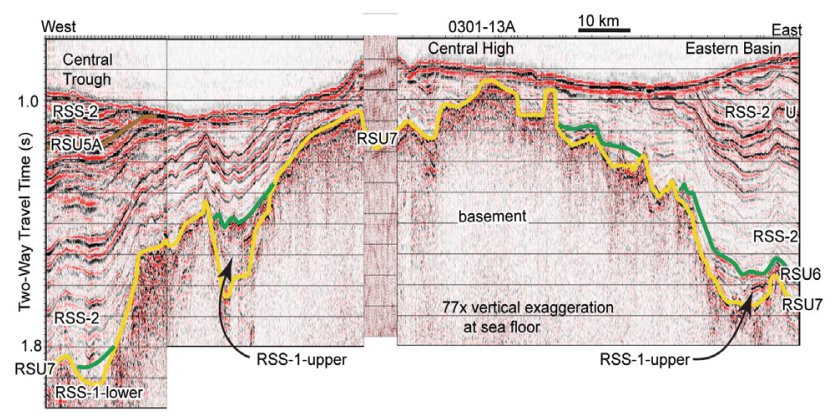

Figure 2. Migrated profile NBP0301-13A (Fig 1). RSS-2 is interpreted over $\mathrm{CH}$, but thins and onlaps basement from both CT and EB. Thin and discontinuous RSS-1upper suggests subsidence below sea level in the early Oligocene. A $\sim 6 \mathrm{~km}$ gap is filled with single channel data. 


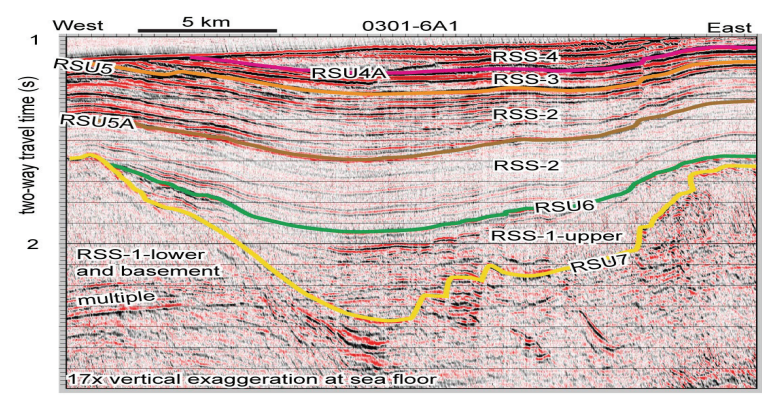

Figure 3. Coulman High migrated profile NBP0301-6A1 (Fig. 1). RSS-1-upper infills basement grabens and is offset by faults (not drawn in). Small offsets of RSS2RSS4 suggest minor extension into middle Miocene.

by less deformed and slightly faulted RSS-1-upper (Fig. 6; Luyendyk et al., 2001). Large-scale Cretaceous Ross Sea extension is required by paleomagnetic studies (e.g. Luyendyk, et al., 1996) and is recorded in the rocks of western Marie Byrd Land and Colbeck Trough (Siddoway, et al., 2004).

We propose that unconformity RSU6 represents a global climate change and was formed by sea level falls of $\sim 50 \mathrm{~m}$ between 33.7 and $33.5 \mathrm{Ma}$ or 28.3 and $28.1 \mathrm{Ma}$ (Miller, et al., 2005). RSU6 separates acoustically semitransparent reflections above from high-amplitude reflections below that indicate significant changes in depositional environments, possibly related to climate (Figs. 2, 6). We hypothesize RSS-2 strata immediately above RSU6 are synchronous in the basins becoming younger onto the basin flanks because of onlap (Fig. 6). RSS-1-lower and upper need not be the same age between basins. Deposition of RSS-1-upper above RSU7 may represent marine transgression onto the subsiding rifted crust.

We propose Roosevelt Sub-basin was not affected by Tertiary extension because of no faulting within RSS-1upper and no evidence for post Cretaceous deformation in adjacent Marie Byrd Land (Siddoway, et al., 2004). Roosevelt Sub-basin subsided below sea level during the early Cenozoic, resulting in deposition of thick, little deformed RSS-1-upper (Fig 4). Subsidence due to thermal

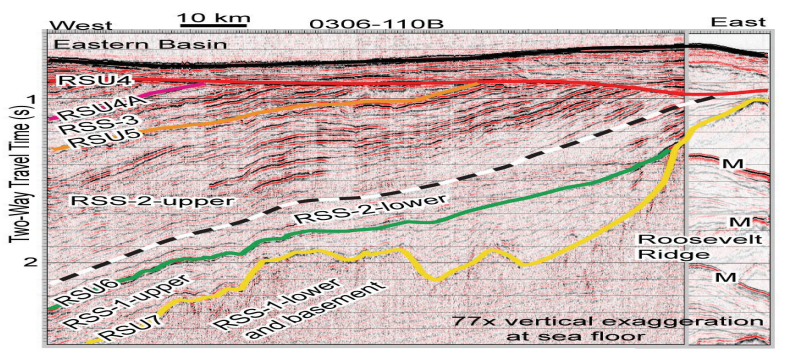

Figure 5. Eastern Basin migrated profile NBP0306-110B (Fig. 1). Two kilometers of RSS-2-RSS-4 thickness was removed by erosion. Uniform tilt of RSS-2 suggests EB subsided during the Oligocene. $\mathrm{M}=$ multiples.

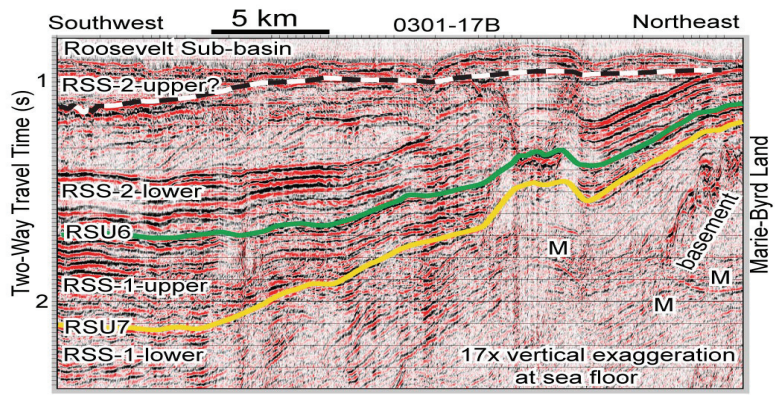

Figure 4. Roosevelt sub-basin migrated seismic profile NBP0301-17B (Fig. 1) showing thick, little-deformed RSS-1-upper and its onlap onto RSU7.

cooling and sediment loading allowed relatively thick RSS-1-upper to be deposited in EB (Fig. 5).

Figure 4 shows onlap of RSS-1-upper onto unconformity RSU7; indicating subsidence was occurring during deposition. The RSS-1-upper deposition pattern in Roosevelt Sub-basin suggests extension was completed here during the L. Cretaceous and the basin was subsiding relative to Roosevelt Ridge and Marie Byrd Land during the early Cenozoic. Major Cenozoic extension across eastern Ross Sea is precluded by plate reconstructions of the Campbell Plateau to the Ross Sea, which separated by sea floor spreading starting at $79.5 \mathrm{Ma}$ (Stock and Cande, 2002). Subsidence models show the easternmost Ross Sea was not affected significantly by Cenozoic extension (Decesari, 2006).

The deformed nature of RSS-1-upper in the western EB (Fig. 2) suggests this portion of the basin extended in the early Cenozoic. This is supported by subsidence modeling (Decesari, 2006). Central Trough may not have completely subsided below sea level until the early Oligocene, because RSS-1-upper is thin to missing in the western part of the trough near the ice shelf edge (Fig. 6). Onlap fill of RSS-2 in basins, erosion on the basin flanks, and tilting suggest vertical motions during Oligocene to early Miocene time. Figure 5 illustrates part of the $2 \mathrm{~km}$ thickness of RSS-2 through RSS-4 removed by glacial erosion between EB and Roosevelt Ridge.

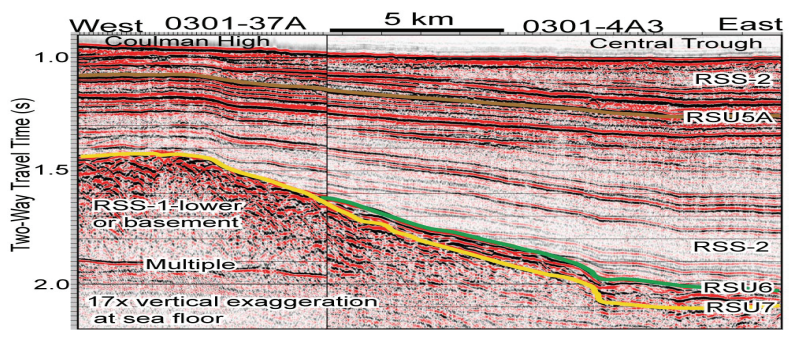

Figure 6. Non-migrated profiles NBP03010-37A \& NBP030-4A3 (Fig. 1). Thin RSS-1-upper suggests deposition near sea level, with subsidence during the Oligocene \& Miocene forming the modern sedimentary basin. 
We hypothesize that a succession of ice sheets removed strata on the basin margin while subsidence preserved strata in the basin center. Bathymetric relief may have existed at $\mathrm{CH}$ during Oligocene time, increasing during the late Oligocene-early Miocene. This is consistent with RSS-2 thinning onto $\mathrm{CH}$ from the east and west by onlap of its base and erosion of its top (Fig. 2 ). The thin RSS-1-upper suggests accommodation space was limited, and a deep bathymetric CT did not exist. Based on these stratigraphic interpretations, we suggest western EB, CT, and possibly VLB formed during and after Cenozoic extension. Easternmost EB developed relief during the Oligocene, and relief of Roosevelt Subbasin grew through the early Cenozoic, consistent with the subsidence models derived by Decesari. (2006).

We do not interpret any significant extension above RSU6 in CT and on CMH. This suggests most Cenozoic extension in CT and on CMH was completed by RSU6 time ( $\sim 30 \mathrm{Ma})$ and was followed by thermal subsidence. Several faults are interpreted to cut RSU6 on $\mathrm{CMH}$ suggesting minor extension lasted into the late Oligocene there (Fig. 3). In VLB, the early Miocene part of RSS-2 is offset by normal faults indicating extension continued to at least the Miocene after CT and $\mathrm{CMH}$ extension ended. Active volcanism in the Terror Rift suggests some VLB extension is ongoing.

Cenozoic Ross Sea extension can be explained by Cande et al. (2000), who interpret $180 \mathrm{~km}$ of middle Eocene to late Oligocene E-W seafloor spreading north of the western Ross Sea, across the Adare Trough (Fig. 1). Other studies have Cenozoic extension limited only to VLB (Davey, et al., 2006). Continuity of a magnetic anomaly between Adare Trough and Northern Basin was part of an argument to preclude transfer of extension to the east (Cande and Stock, 2006). However, part of Adare extension, could be transferred east of Northern Basin, and to southern CT (e.g. Salvini, et al., 1997). Continuity of magmatic intrusions from Adare spreading center to Northern Basin could both co-exist with, and postdate, transfer of extension to CT.

We suggest extension ended sooner in the eastern Ross Sea and continued later in the western Ross Sea. The present day VLB is only $150 \mathrm{~km}$-wide. Accommodation of $180 \mathrm{~km}$ or more of E-W extension is not possible in the VLB. Either extension decreases rapidly towards a nearby pole of rotation to the south (Davey, et al., 2006), or part of Adare extension must affect $\mathrm{CMH}, \mathrm{CT}$, and possibly the western EB.

Acknowledgements. We acknowledge the captain, crew, and scientific party of the US RVIB Nathaniel B. Palmer cruises $0301 \& 0306$. Students from UCSB and UNC participated in our field programs. Thanks to Dan Herold and Matt Ralston of Parallel Geophysics Corp for help and advice with processing. Seismic Micro Corp. provided Kingdom Suite interpretation software. Phil Bart, Fred Davey and Joan Stock gave useful comments. Supported by NSF grants OPP0088143 (Luyendyk), OPP0087392 (Bartek), and OPP0087983 (Diebold). Contribution 0807 of the Institute for Crustal Studies, UCSB.

\section{References}

ANTOSTRAT (1995), Seismic Stratigraphic Atlas of the Ross Sea, in

Geology and Seismic Stratigraphy of the Antarctic Margin, edited by A. K. Cooper, Barker, P. F., Brancolini, G., p. 22 plates, American Geophysical Union, Washington, D.C.

Brancolini, G., A. K. Cooper, and F. Coren (1995), Seismic Facies and Glacial History in the Western Ross Sea (Antarctica), in Geology and seismic stratigraphy of the Antarctic margin, edited by A. K. Cooper, et al., pp. 209-234, Amer. Geophys. Union, Washington, D. C.

Cande, S. C., and J. M. Stock (2006), Constraints on the timing of extension in the Northern Basin, Ross Sea, in Antarctica, Contributions to Global Earth Science, edited by D. K. Futterer, et al., Wurzburg, Germany.

Cande, S. C., J. M. Stock, D. Müller, and T. Ishihara (2000), Cenozoic Motion between East and West Antarctica, Nature, 404, 145-150.

Cape-Roberts-Science-Team (2000), Summary of Results, Initial Report on CRP-3, Cape Roberts Project, Antarctica, Terra Antarctica, 7, 185-209.

Cooper, A. K., F. J. Davey, and J. C. Behrendt (1987), Seismic stratigraphy and structure of the Victoria Land Basin, western Ross Sea, Antarctica, in The Antarctic Continental Margin: Geology and Geophysics of the Western Ross Sea, edited by A. K. Cooper and F. J. Davey, pp. 27-65, Circum-Pacific Council for Energy and Mineral Resources, Houston, Texas.

Davey, F. J., and G. Brancolini (1995), The Late Mesozoic and Cenozoic structural setting of the Ross Sea region, in Geology and Seismic Stratigraphy of the Antarctic Margin, edited by A. K. Cooper, et al., pp. 167-182, Amer. Geophys. Union, Washington, D.C.

Davey, F. J., G. Brancolini, R. J. Hamilton, S. A. Henrys, C. C. Sorlien, and L. R. Bartek (2000), A revised correlation of seismic stratigraphy at the Cape Roberts drillsites with the seismic stratigraphy of the Victoria Land basin, in Studies from the Cape Roberts Project, Ross Sea, Antarctica; scientific results of CRP-2/2A; Part I, Geophysics and physical properties studies for CRP-2/2A, edited by F. J. Davey and R. D. Jarrard, pp. 215220, Terra Antarctica.

Davey, F. J., S. C. Cande, and J. M. Stock (2006), Extension in the western Ross Sea region-links between Adare Basin and Victoria Land Basin, Geophysical Research Letters, 33, doi:10.1029/2006GL027383.

Decesari, R. C. (2006), The Mesozoic and Cenozoic Depositional, Structural, and Tectonic Evolution of the Ross Sea, Antarctica, doctoral thesis, 232 pp, University of California, Santa Barbara.

DeSantis, L., S. Prato, G. Brancolini, M. Lovo, and L. Torelli (1999), The Eastern Ross Sea continental shelf during the Cenozoic: Implications for the West Antarctic ice sheet development, Global Plan. Ch., 23, 173-196.

Luyendyk, B. P., S. Cisowski, C. H. Smith, S. M. Richard, and D. L. Kimbrough (1996), Paleomagnetic study of the northern Ford Ranges, western Marie Byrd Land, West Antarctica: a middle Cretaceous pole, and motion between West and East Antarctica? Tectonics, 15, 122-141.

Luyendyk, B. P., C. C. Sorlien, D. S. Wilson, L. R. Bartek, and C. H. Siddoway (2001), Structural and tectonic evolution of the Ross Sea rift in the Cape Colbeck region, Eastern Ross Sea, Antarctica, Tectonics, 20, 933 958.

Miller, K. G., M. A. Kominz, J. V. Browning, J. D. Wright, G. S. Mountain, M. E. Katz, P. J. Sugarman, B. S. Cramer, N. Christie-Blick, and S. F. Pekar (2005), The Phanerozoic Record of Global Sea-Level Change, Science, 310, 1293-1298.

Salvini, F., G. Brancolini., M. Busetti, F. Storti, F. Mazzarini, F. Coren (1997), Cenozoic geodynamics of the Ross sea region, Antarctica: Crustal extension, intraplate strike-slip faulting, and tectonic inheritance, J. Geophys. Res., 102, 24669-24696.

Siddoway, C. S., S. L. Baldwin, P. G. Fitzgerald, C. M. Fanning, and B. P. Luyendyk (2004), Ross Sea mylonites and the timing of continental extension between East and West Antarctica, Geology, 32, 57-60.

Sorlien, C. C., Luyendyk, B. P., Wilson, D S.., Decesari, R. C., Bartek, L. R., and Diebold, J. B., Oligocene development of the West Antarctic Ice Sheet recorded in eastern Ross Sea strata, Geology, v. 35, p. 467-470, doi: 10.1130/G23387A.1

Steinhauff, D. M., M. E. Renz, D. M. Harwood, and P.-N. Webb (1987), Miocene diatom biostratigraphy of DSDP hole 272: Stratigraphic relationship to the underlying Miocene of DSDP hole 270, Ross Sea, Antarctic J. of the US, 22, 123-125.

Stock, J. M., and S. C. Cande (2002), Tectonic History of Antarctic Seafloor in the Australia-New Zealand-South Pacific Sector: Implications for Antarctic Continental Tectonics, in Antarctica at the Close of a Millennium: Proceedings of the 8th International Symposium on Antarctic Earth Sciences, Wellington, 1999, edited by J. A. Gamble, et al., pp. 251259, The Royal Society of New Zealand, Wellington, New Zealand. 